\title{
AVAILABILITY OF SOIL WATER UNDER TILLAGE SYSTEMS, MULCH MANAGEMENT AND CITRUS ROOTSTOCKS ${ }^{(1)}$
}

\author{
Jonez Fidalski (2), Pedro Antonio Martins Auler ${ }^{(2)}$, José Marcos \\ Garrido Beraldo $^{(3)}$, Celso Jamil Marur ${ }^{(4)}$, Rogério Teixeira de \\ Faria $^{(4)}$ \& Graziela Moraes de Cesare Barbosa ${ }^{(4)}$
}

\begin{abstract}
SUMMARY
The increased availability of soil water is important for the management of non-irrigated orange orchards. The objective of this study was to evaluate the availability of soil water in a Haplorthox (Rhodic Ferralsol) under different tillage systems used for orchard plantation, mulch management and rootstocks in a "Pêra" orange orchard in northwest Paraná, Brazil. An experiment in a split-split-plot design was established in 2002, in an area cultivated with Brachiaria brizantha grass in which three tillage systems (no tillage, conventional tillage and strip-tillage) were used for orchard plantation. This grass was mowed twice a year between the rows, representing two mulch managements in the split plots (no mulching and mulching in the plant rows). The split-split-plots were represented by two rootstocks ("Rangpur" lime and "Cleopatra" mandarin). The soil water content in the plant rows was evaluated in the 0-20 cm layer in 2007 and at 0-20 and $20-40 \mathrm{~cm}$ in 2008-2009. The effect of soil tillage systems prior to implantation of orange orchards on soil water availability was less pronounced than mulching and the rootstocks. The soil water availability was lower when "Pêra" orange trees were grafted on "Cleopatra" mandarin than on "Rangpur" lime rootstocks. Mulching had a positive influence on soil water availability in the sandy surface layer (0$20 \mathrm{~cm}$ ) and sandy clay loam subsurface $(20-40 \mathrm{~cm})$ of the soil in the spring. The production of $B$. brizantha between the rows and residue disposal in the plant rows as mulch increased water availability to the "Pêra" orange trees.
\end{abstract}

Index terms: Brachiaria brizantha, no tillage, soil management, soil texture, time domain reflectometry.

\footnotetext{
(1) Submitted April 2009, approved Frebuary 2010.

(2) Agronomic Institute of Paraná. Caixa Postal 564, CEP 87701-970 Paranavaí (PR), Brazil. E-mail: fidalski@iapar.br, aulerpe@iapar.br

(3) São Paulo State University, Department of Soil Science, Campus of Jaboticabal, CEP 14884-900 Jaboticabal (SP). Scholarships CAPES. E-mail: jmgberaldo@yahoo.com.br

(4) Agronomic Institute of Paraná. Caixa Postal 481, CEP 86001-970 Londrina (PR), Brazil. E-mail: cjmarur@iapar.br, rtfaria@iapar.br, graziela_barbosa@iapar.br
} 


\title{
RESUMO: DISPONIBILIDADE DE ÁGUA NO SOLO EM SISTEMAS DE PREPARO, MANEJO DA COBERTURA MORTA E PORTA- ENXERTOS DE CITROS
}

\begin{abstract}
O aumento da disponibilidade de água no solo é importante para o manejo de pomares de laranja não irrigados. O objetivo deste trabalho foi avaliar a água em um Latossolo Vermelho distrófico em sistemas de preparo utilizados para implantação do pomar, manejo da cobertura morta e porta-enxertos em pomar de laranjeira 'Pêra', no noroeste do Paraná. Um experimento no esquema de parcelas subsubdivididas foi implantado em 2002, em área com pastagem de braquiária-brizanta (Brachiaria brizantha), utilizando três sistemas de preparo do solo nas parcelas (sem revolvimento, com revolvimento e em faixas). A gramínea foi roçada duas vezes ao ano nas entrelinhas, constituindo dois tratamentos nas subparcelas (sem e com cobertura morta nas linhas das plantas). Nas subsubparcelas, foram avaliados dois porta-enxertos (limoeiro 'Cravo' e tangerineira 'Cleópatra'). Nas linhas das plantas, avaliou-se o conteúdo de água no solo nas camada de 0-20 cm em 2007 e 0-20 e no de 20$40 \mathrm{~cm}$ em 2008-2009. O efeito do preparo do solo no conteúdo de água foi verificado somente em 2007, e o efeito da cobertura morta e dos porta-enxertos, em 2007-2009. O cultivo de laranjeira 'Pêra' enxertada sobre tangerineira 'Cleópatra' reduziu o conteúdo de água do solo em relação ao limoeiro "Cravo". A cobertura morta influenciou positivamente o conteúdo de água na superfície (0-20 cm; textura arenosa) e na subsuperfície do solo (20-40 cm; textura média) durante a primavera. A produção de braquiária-brizanta nas entrelinhas e seu manejo nas linhas das plantas como cobertura morta aumentaram a disponibilidade de água para as laranjeiras.
\end{abstract}

Termos de indexação: braquiária brizanta, plantio direto, manejo do solo, textura do solo, reflectometria do domínio no tempo.

\section{INTRODUCTION}

The availability of soil water in non-irrigated orange orchards can be increased by not disturbing the soil and mulching between plant rows to reduce evaporation. For the implantation of orange orchards, the soil is usually tilled and plants and residue are incorporated leaving the soil temporarily bare, which aggravates soil and water losses (Politano \& Pissarra, 2005). Experimental results have shown the possibility of using reduced soil tillage for the implantation of orange orchards (Auler et al. 2008b; Fidalski et al., 2009), maintaining permanently vegetated rows without soil disturbance by tillage after the establishment of the orchard (Fidalski et al., 2007).

The large-scale external input of organic residues for mulch management in orchards would be economically unfeasible (Hogue \& Neilsen, 1987). Alternatively, there is the possibility of producing grass biomass between the rows of orange orchards with mechanical mowing for mulch accumulation on the soil in plant rows (Beraldo et al. 2007; Bremer Neto et al., 2008; Fidalski et al., 2009). However, the effect of mulching in the plant rows has not been evaluated for the possible responses of rootstocks, which may differ in soil water uptake and consumption.

"Rangpur" lime is the most commonly used rootstock in Brazilian orange orchards; an alternative rootstock option would be the mandarin "Cleopatra" (Pompeu Junior, 2005). Studies have shown that the canopy development of grafts on this rootstock is better than on "Rangpur" (Stenzel et al., 2005a; Auler et al., 2008a). However, "Cleopatra" mandarin rootstocks are more susceptible to water stress than "Rangpur" lime (Pompeu Junior, 2005), probably due to a higher transpiration rate (Cintra et al., 2000).

In the northwest of Paraná, water deficits in orange orchards occur during July and August, with probabilities of 76,56 and $42 \%$, respectively, for periods of 5, 10 and 20 days (Calheiros et al., 1992). In this region, Stenzel et al. (2005b) found that water stress reduced the vegetative growth rate of "Folha Murcha" orange trees between March and April.

The objective of this study was to evaluate the soil water availability under different tillage systems prior to orange implantation as well as mulch management systems in plant rows of a "Pêra" orange orchard grafted on the rootstocks "Rangpur" lime and "Cleopatra" mandarin in a Haplorthox in northwest Paraná.

\section{MATERIAL AND METHODS}

The study was carried out in an experimental area with "Pêra" orange trees, introduced in 2002, spaced 
$6.8 \times 3.5 \mathrm{~m}$, on the farm Ipiranga in Paranavaí, northwest of Paraná $\left(23^{\circ} 6\right.$ ' S, $52^{\circ} 25^{\prime} \mathrm{W}, 450 \mathrm{~m}$ asl), slightly undulated relief with a maximum gradient of $6 \mathrm{~cm} \mathrm{~m}^{-1}$. Prior to orchard implantation the area had been cropped with long-term pasture (Brachiaria brizantha). The climate is subtropical (Cfa), with an average annual rainfall of 1,500 $\mathrm{mm}$ (Iapar, 2000). The soil is a Haplorthox (Rhodic Ferralsol) of sandy and sandy clay loam texture, respectively (Santos et al., 2006), in the surface and subsurface layers. The horizon (0-20 cm layer) is composed of $110 \mathrm{~g} \mathrm{~kg}^{-1}$ clay, $15 \mathrm{~g} \mathrm{~kg}^{-1}$ silt and $875 \mathrm{~g} \mathrm{~kg}^{-1}$ sand; the Bw horizon (20-200 cm layer) consists of $170 \mathrm{~g} \mathrm{~kg}^{-1}$ clay, $10 \mathrm{~g} \mathrm{~kg}^{-1}$ silt and $820 \mathrm{~g} \mathrm{~kg}^{-1}$ sand. Particle size was determined by the pipette method (Claessen, 1997).

The experiment was arranged in a randomized block design in split-split-plot with 12 treatments and four replications. Three soil tillage systems were considered as plots (no-tillage, conventional tillage and strip-tillage), two mulch managements (no mulching and mulching) in orange tree rows as split plots and two rootstocks as the split-split plots ("Rangpur" lime and "Cleopatra" mandarin rootstocks). In each plot, 15 plants were grown in three rows with five plants. No-tillage consisted of desiccation of $B$. brizantha in $2 \mathrm{~m}$ wide strips using glyphosate herbicide; conventional tillage consisted of plowing the entire area to a depth of 0-20 cm and two diskings in the 0 $10 \mathrm{~cm}$ layer; and the strip tillage consisted of plowing and harrowing in narrow $2 \mathrm{~m}$ wide strips for soil preparation in the plant rows, without killing and incorporating $B$. brizantha growing between the rows (Auler et al., 2008b). Continuous 0-30 cm furrows spaced $6.8 \mathrm{~m}$ apart were then opened in all three systems, with holes spaced $3.5 \mathrm{~m}$ apart for the orange trees.

In the treatment no mulching in the plant rows, $B$. brizantha was cut and left between the orchard rows. In the treatment mulching in the plant rows, $B$. brizantha was cut with a mowing machine that threw the grass onto the plant rows, forming a mulch cover there (Figure 1). These practices were performed 2003 , in the beginning and end of the rainy season, i.e., in November and March. The average dry mass production of $B$. brizantha was around $5 \mathrm{t} \mathrm{ha}^{-1}$ (Beraldo et al., 2007). The weed in the plant rows without mulching was controlled by hand-weeding. To prevent the growth of $B$. brizantha in the tree rows, herbicide (glyphosate) was applied every year, to keep the grass development off the rows and at a distance of $50 \mathrm{~cm}$ from the projection of the canopy of the orange trees.

The first cycle of soil water availability evaluations was performed only in two tillage systems (conventional tillage and no-tillage), consisting of 17 measurements within 100 days (March 22 to June 29, 2007) using the time domain reflectometry technique (TDR). Probes with three steel rods (diameter $4 \mathrm{~mm}$, length $20 \mathrm{~cm}$ ), spaced $1 \mathrm{~cm}$ apart, were vertically installed

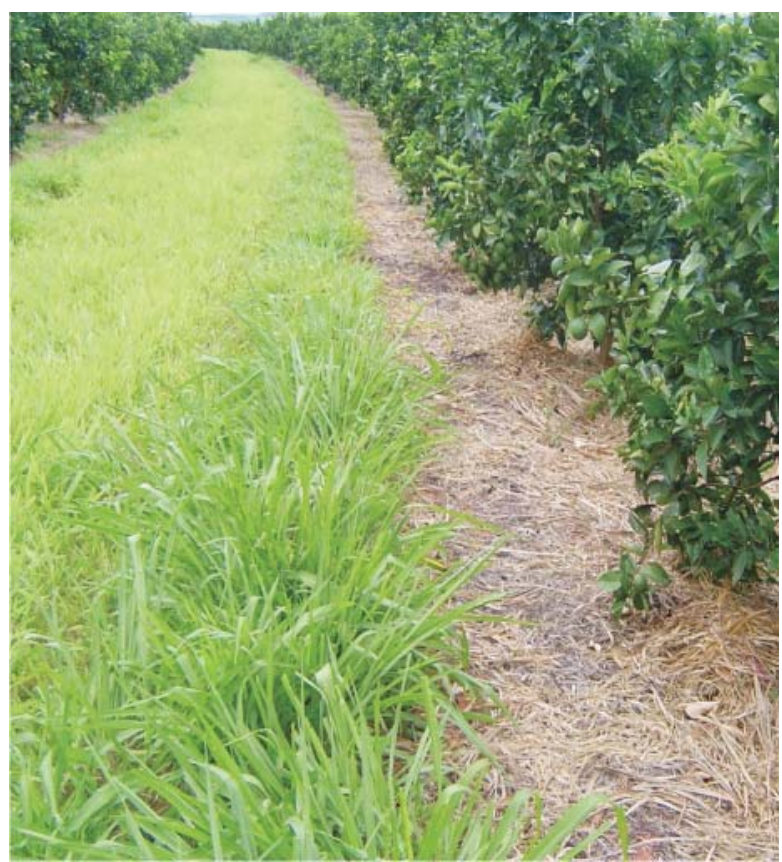

Figure 1. Mulch management systems in a "Pêra" orange orchard cultivated with Brachiaria brizantha grass (Pedro Antonio Martins Auler IAPAR).

in the rows in the $0-20 \mathrm{~cm}$ layer and $75 \mathrm{~cm}$ away from the trunk of the orange trees. The soil dielectric constant was measured with a Tektronix $1502 \mathrm{~B}$ cable tester and used to estimate the soil water content by equation (Topp et al., 1980). The second evaluation cycle of soil water was carried out in all three tillage systems (no-tillage, conventional tillage and striptillage), based on 12 disturbed soil samples collected in four drying periods: $1^{\text {st }}$ (November 7, 14, 21, and 27, 2008), $2^{\text {nd }}$ (March 10, 17 and 24, 2009), $3^{\text {rd }}$ (May 18 and 25,2009 ) and $4^{\text {th }}$ (July 3,8 and 21, 2009), respectively, in the Spring, Summer, Autumn, and Winter. On each date, a soil sample was collected in the plant row, between two orange trees, about $75 \mathrm{~cm}$ away from the orange tree trunk. Soil samples were collected with an auger probe (diameter $2.5 \mathrm{~cm}$ ) from the layers $0-20$ and $20-40 \mathrm{~cm}$, filled in aluminum cans and stored in a polystyrene box followed by gravimetric determination of water according to Claessen (1997).

The rainfall during the two series of soil water evaluations was measured at the weather station of Iapar in Paranavaí, around $3 \mathrm{~km}$ away from the experimental area.

Soil water content data were subjected to analysis of variance for each measurement date using the mathematical model of randomized blocks in the scheme of split-split-plots and the means compared by the Tukey test (Banzatto \& Kronka, 2006). Soil water content data in the 0-20 and 20-40 cm layers 
of the soil tillage systems ( $\mathrm{n}=18)$, mulching $(\mathrm{n}=24)$ and rootstocks $(n=24)$ were compared by the t test.

\section{RESULTS AND DISCUSSION}

During the first series of soil water content evaluations (2007) 19 rains of 0.2 to $36.9 \mathrm{~mm}$ (total amount of $147.7 \mathrm{~mm}$ ) were observed (Figure 2a), and four periods of soil drying, beginning on the $81^{\text {st }}$ day (March 22), 111 ${ }^{\text {st }}$ day (April 11), 117 th day (April 27), and $149^{\text {th }}$ day (May 29) (Figure 2b). The drying periods lasted, respectively, 20, 16, 32, and 31 days. The soil water content was highest on March $22\left(0.138 \mathrm{~m}^{3} \mathrm{~m}^{-3}\right)$ and lowest on June $29\left(0.075 \mathrm{~m}^{3} \mathrm{~m}^{-3}\right)$ (Figure $\left.2 \mathrm{~b}\right)$, corresponding to the water potentials, respectively, to field capacity $(-8 \mathrm{kPa})$ and wilting point $(-1,500 \mathrm{kPa})$ as found by Fidalski \& Tormena (2007) in a similar soil study.

From March 22 to June 29, 2007, during the stages of high water demand of the trees (fruit development and maturation), two-factor interactions ( $p \leq 0.05$ ) were observed for the soil tillage systems and mulching; soil tillage systems and rootstocks, and mulching and rootstocks on April 18, and between the soil tillage systems and mulching on April 27 (Table 1). The soil water content in the 0-20 cm layer in the plant rows decreased on April 18 in the treatments no-tillage with mulching (Table 2), notillage with rootstock "Cleopatra" mandarin, and mulching with "Cleopatra" mandarin (Table 3). On April 27, the soil water in the same layer decreased again with the interaction between the treatments no-tillage with mulching and conventional tillage no mulching (Table 2). The reduction in soil water on
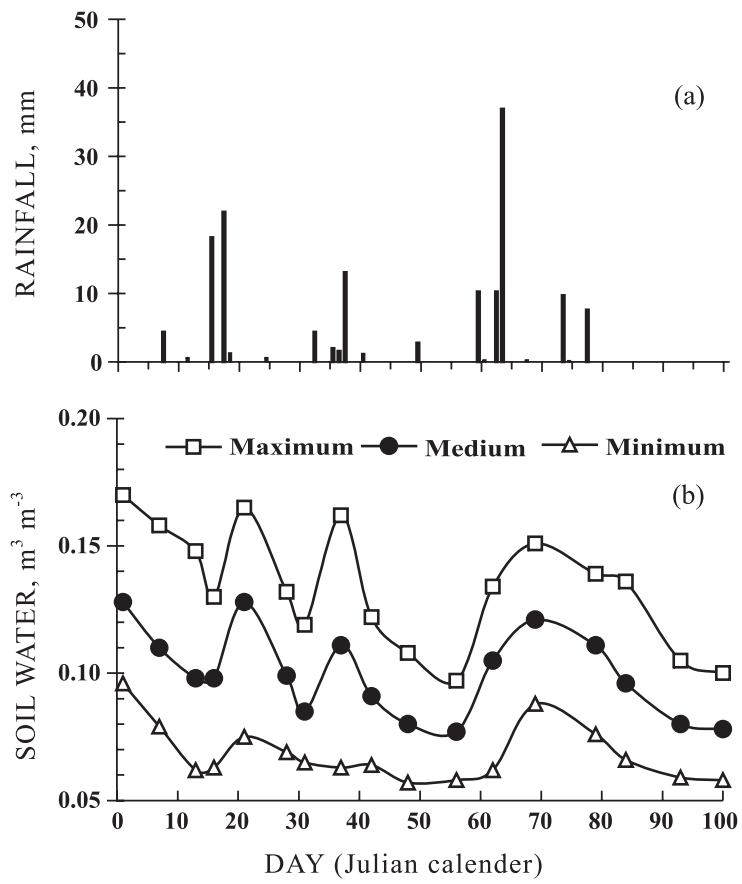

Figure 2. Rainfall (a) and soil water in the $0-20 \mathrm{~cm}$ layer (b) in the assessment period of 100 days (March 22 to June 27, 2007).

April 18 was observed under "Pêra" orange trees grafted onto "Cleopatra" mandarin (Table 3), which is a rootstock with a higher water demand than Rangpur" lime"(Cintra et al., 2000).

In the second series of evaluations of soil water, only individual effects of mulching and rootstocks were observed ( $\mathrm{p} \leq 0.05$ ) in the layers $0-20$ and $20-40 \mathrm{~cm}$ (Table 4). The evaluations were conducted after a total

Table 1. Probabilities of influence of the factors F1 (soil tillage systems), F2 (mulching management) and F3 (rootstocks) for soil water volume in the 0-20 cm layer by the F test, in 17 assessments (March 22 to June 27, 2007), corresponding to 100 days, in the Julian calendar

\begin{tabular}{|c|c|c|c|c|c|c|c|c|}
\hline Date & Day & F1 & F2 & F3 & F1 xF2 & F1xF3 & F2xF3 & F1xF2xF3 \\
\hline $3 / 22 / 2007$ & $81^{\text {st }}$ & 0.61 & 0.26 & 0.28 & 0.14 & 0.36 & 0.56 & 0.71 \\
\hline $3 / 28 / 2007$ & $87^{\text {th }}$ & 0.95 & 0.37 & 0.68 & 0.21 & 0.12 & 0.23 & 0.25 \\
\hline $4 / 3 / 2007$ & $93^{\text {th }}$ & 0.96 & 0.71 & 0.73 & 0.30 & 0.31 & 0.49 & 0.45 \\
\hline $4 / 6 / 2007$ & $96^{\text {th }}$ & 0.80 & 0.79 & 0.76 & 0.23 & 0.76 & 0.08 & 0.13 \\
\hline $4 / 11 / 2007$ & 101 st & 0.89 & 0.37 & 0.71 & 0.82 & 0.50 & 0.33 & 0.87 \\
\hline $4 / 18 / 2007$ & $108^{\text {th }}$ & 0.95 & 0.09 & 0.07 & 0.05 & 0.01 & 0.04 & 0.84 \\
\hline $4 / 24 / 2007$ & $111^{\text {st }}$ & 0.55 & 0.68 & 0.70 & 0.24 & 0.40 & 0.36 & 0.61 \\
\hline $4 / 27 / 2007$ & $117^{\text {th }}$ & 0.88 & 0.84 & 0.15 & 0.01 & 0.52 & 0.24 & 0.95 \\
\hline $5 / 2 / 2007$ & 122 nd & 0.75 & 0.12 & 0.27 & 0.16 & 0.73 & 0.37 & 0.65 \\
\hline $5 / 8 / 2007$ & $128^{\text {th }}$ & 0.42 & 0.11 & 0.31 & 0.31 & 0.66 & 0.40 & 0.90 \\
\hline $5 / 16 / 2007$ & $136^{\text {th }}$ & 0.36 & 0.50 & 0.61 & 0.44 & 0.87 & 0.39 & 0.63 \\
\hline $5 / 22 / 2007$ & 142 nd & 0.86 & 0.13 & 0.06 & 0.26 & 0.79 & 0.21 & 0.62 \\
\hline $5 / 29 / 2007$ & $149^{\text {th }}$ & 0.91 & 0.34 & 0.21 & 0.16 & 0.55 & 0.08 & 0.60 \\
\hline $6 / 8 / 2007$ & $159^{\text {th }}$ & 0.74 & 0.93 & 0.64 & 0.79 & 0.72 & 0.38 & 0.78 \\
\hline $6 / 13 / 2007$ & $164^{\text {th }}$ & 0.74 & 0.86 & 0.61 & 0.73 & 0.55 & 0.48 & 0.59 \\
\hline $6 / 22 / 2007$ & $173^{\mathrm{rd}}$ & 0.60 & 0.81 & 0.72 & 0.27 & 0.63 & 0.36 & 0.61 \\
\hline $6 / 29 / 2007$ & $180^{\text {th }}$ & 0.52 & 0.65 & 0.58 & 0.23 & 0.70 & 0.42 & 0.83 \\
\hline
\end{tabular}


Table 2. Soil water content in the 0-20 cm layer for soil tillage systems and mulch management in $2007^{(1)}$

\begin{tabular}{lcc}
\hline \multirow{2}{*}{$\begin{array}{c}\text { Soil tillage } \\
\text { systems }\end{array}$} & \multicolumn{2}{c}{ Mulch management } \\
\cline { 2 - 3 } & No mulcuhing & Mulching \\
\hline & $4 / 18 / 2007\left(108^{\text {th }}\right.$ day on the Julian calendar $)$ \\
& $0.106 \mathrm{Aa}$ & $0.094 \mathrm{Ba}$ \\
No tillage & $0.099 \mathrm{Aa}$ & $0.099 \mathrm{Aa}$ \\
Conventional tillage & & $0.106 \mathrm{Ba}$ \\
& $4 / 27 / 2007\left(117^{\text {th }}\right.$ day on the Julian calendar $)$ \\
No tillage & $0.117 \mathrm{Aa}$ & $0.116 \mathrm{Aa}$ \\
Conventional tillage & $0.104 \mathrm{Ba}$ & \\
(1) Means followed by the same capital letter for soil tillage \\
system (row) and lower-case letter for mulching (column) did
\end{tabular}

rainfall of $62.9 \mathrm{~mm}$ (November 6 and 7,2008 ), $25.8 \mathrm{~mm}$ (March 8 and 10, 2009), $36.4 \mathrm{~mm}$ (May 14 and 15, 2009); and $18.1 \mathrm{~mm}$ (July 1 and 2, 2009). Four periods of soil drying were observed in the four seasons, with a range of soil water from 0.029 to $0.097 \mathrm{~g} \mathrm{~g}^{-1}$ (Tables 5, 6 and 7), which corresponded, respectively, to soil water potentials below wilting point $(-1,500 \mathrm{kPa})$ and near to field capacity $(-8 \mathrm{kPa})$ which are close to the results of Fidalski et al. (2008) in a similar soil under orange.
Unlike in the first evaluation cycle, soil tillage systems did not affect the soil water content during the four drying periods (Table 5), possibly due to the long period after the last soil disturbance by tillage prior to orchard orange implantation (2002), because there was no change in the soil density in this experiment (Fidalski et al., 2009). Under mulching,

Table 3. Soil water content in the 0-20 cm layer for soil tillage systems mulch management and rootstocks in $2007^{(1)}$

\begin{tabular}{lcc}
\hline \multirow{2}{*}{$\begin{array}{c}\text { Soil tillage } \\
\text { systems and } \\
\text { mulch manag. }\end{array}$} & \multicolumn{2}{c}{ Rootstocks } \\
\cline { 2 - 3 } & $\begin{array}{c}\text { "Rangpur" } \\
\text { lime }\end{array}$ & $\begin{array}{c}\text { "Cleopatra" } \\
\text { mandarin }\end{array}$ \\
\cline { 2 - 3 } & \multicolumn{2}{c}{$\mathrm{m}^{3} \mathrm{~m}^{3}{ }^{2 / 18 / 2007\left(108^{\text {th }}\right.}$ day on the Julian calendar $)$} \\
No tillage & $0.110 \mathrm{Aa}$ & $0.090 \mathrm{Ba}$ \\
Conventional tillage & $0.096 \mathrm{Aa}$ & $0.102 \mathrm{Aa}$ \\
& & \\
No mulching & $4 / 18 / 2007\left(108^{\text {th }}\right.$ day on the Julian calendar $)$ \\
Mulching & $0.102 \mathrm{Aa}$ & $0.103 \mathrm{Aa}$ \\
& $0.104 \mathrm{Aa}$ & $0.089 \mathrm{Bb}$
\end{tabular}

(1) Means followed by the same capital letter for soil tillage system (row) and for mulching (row) and lower-case letter for rootstocks (column) did not differ by the Tukey test $(\mathrm{p}<0.05)$.

Table 4. Probabilities by the F test of the factors of variation F1 (soil tillage systems), F2 (mulch management) and F3 (rootstocks) for soil water content in the 0-20 cm and 20-40 cm layers, in 12 evaluations (November 7, 2008, to July 21, 2009)

\begin{tabular}{|c|c|c|c|c|c|c|c|}
\hline Date & F1 & F2 & F3 & F1xF2 & F1xF3 & F2xF3 & F1xF2xF3 \\
\hline & & & & $0-20 \mathrm{~cm}$ & & & \\
\hline $11 / 7 / 2008$ & 0.72 & 0.34 & 0.78 & 0.62 & 0.17 & 0.22 & 0.66 \\
\hline $11 / 14 / 2008$ & 0.30 & $<0.01$ & 0.12 & 0.43 & 0.80 & 0.48 & 0.84 \\
\hline $11 / 21 / 2008$ & 0.92 & $<0.01$ & 0.64 & 0.59 & 0.77 & 0.29 & 0.63 \\
\hline $11 / 27 / 2008$ & 0.33 & 0.07 & 0.95 & 0.21 & 0.87 & 0.14 & 0.29 \\
\hline $3 / 10 / 2009$ & 0.79 & 0.66 & 0.17 & 0.82 & 0.49 & 0.55 & 0.98 \\
\hline $3 / 17 / 2009$ & 0.38 & 0.93 & 0.02 & 0.06 & 0.93 & 0.63 & 0.19 \\
\hline $3 / 24 / 2009$ & 0.96 & $<0.01$ & 0.33 & 0.34 & 0.99 & 0.22 & 0.54 \\
\hline $5 / 18 / 2009$ & 0.38 & 0.36 & 0.89 & 0.77 & 0.76 & 0.13 & 0.98 \\
\hline $5 / 25 / 2009$ & 0.88 & 0.81 & 0.04 & 0.38 & 0.65 & 0.94 & 0.26 \\
\hline $7 / 3 / 2009$ & 1.00 & 0.97 & 0.54 & 0.61 & 0.28 & 0.50 & 0.48 \\
\hline $7 / 8 / 2009$ & 0.62 & 0.01 & 0.27 & 0.55 & 0.96 & 0.75 & 0.93 \\
\hline \multirow[t]{2}{*}{$7 / 21 / 2009$} & 0.17 & 0.02 & 0.11 & 0.59 & 0.58 & 0.24 & 0.43 \\
\hline & & & & $20-40 \mathrm{~cm}$ & & & \\
\hline $11 / 7 / 2008$ & 0.26 & 0.72 & 0.89 & 0.78 & 0.59 & 0.10 & 0.44 \\
\hline $11 / 14 / 2008$ & 0.55 & 0.12 & 0.21 & 0.02 & 0.93 & 0.46 & 0.66 \\
\hline $11 / 21 / 2008$ & 0.65 & $<0.01$ & 0.05 & 0.82 & 0.16 & 0.30 & 0.82 \\
\hline $11 / 27 / 2008$ & 0.76 & 0.01 & 0.83 & 0.21 & 0.31 & 0.17 & 0.52 \\
\hline $3 / 10 / 2009$ & 0.26 & 0.06 & 0.43 & 0.98 & 0.74 & 0.86 & 0.75 \\
\hline $3 / 17 / 2009$ & 0.79 & 0.09 & 0.36 & 0.07 & 0.92 & 0.80 & 0.81 \\
\hline $3 / 24 / 2009$ & 0.40 & 0.06 & 0.02 & 0.92 & 0.24 & 0.52 & 0.90 \\
\hline $5 / 18 / 2009$ & 0.41 & 0.21 & 0.42 & 0.75 & 0.52 & 0.40 & 0.79 \\
\hline $5 / 25 / 2009$ & 0.77 & 0.45 & 0.55 & 0.67 & 0.37 & 0.40 & 0.89 \\
\hline $7 / 3 / 2009$ & 0.78 & 0.16 & 0.21 & 0.30 & 0.62 & 0.48 & 0.96 \\
\hline $7 / 8 / 2009$ & 0.59 & 0.59 & 0.96 & 0.73 & 0.99 & 0.45 & 0.57 \\
\hline $7 / 21 / 2009$ & 0.27 & 0.17 & 0.77 & 0.59 & 0.91 & 0.93 & 0.41 \\
\hline
\end{tabular}


the soil retained most water in the 0-20 cm surface layer (sandy texture) on November 14 and 21, 2008, March 24, 2009, and July 8 and 21, 2009, which was related to the soil water content in the $20-40 \mathrm{~cm}$ layer (sandy clay loam texture) on 21/11/2008 and 27/11/ 2008 (Table 6). The influence of clay content on soil water relationships were reported by Machado et al. (2008).
The soil water contents on March 17 and May 25, 2009 in the 0-20 cm layer and on November 21, 2008 and March 24, 2009 in the 20-40 cm layer were greater in the rows of orange tree grafted on "Rangpur" lime than on "Cleopatra" mandarin rootstock (Table 7). This finding confirm results of the first evaluation cycle indicating a higher transpiration rate of orange

Table 5. Soil water content in four drying periods and four seasons between 2008 and 2009 under soil tillage systems $^{(1)}$

\begin{tabular}{|c|c|c|c|c|c|c|c|c|}
\hline \multirow{2}{*}{$\begin{array}{l}\text { Drying } \\
\text { period }\end{array}$} & \multirow[b]{2}{*}{ Date } & \multirow[b]{2}{*}{ Season } & \multicolumn{3}{|c|}{$0-20 \mathrm{~cm}$} & \multicolumn{3}{|c|}{$20-40 \mathrm{~cm}$} \\
\hline & & & $\begin{array}{c}\text { No } \\
\text { tillage }\end{array}$ & $\begin{array}{l}\text { Strip } \\
\text { tillage }\end{array}$ & $\begin{array}{c}\text { Conventional } \\
\text { tillage }\end{array}$ & $\begin{array}{c}\text { No } \\
\text { tillage }\end{array}$ & $\begin{array}{c}\text { Strip } \\
\text { tillage }\end{array}$ & $\begin{array}{c}\text { Conventional } \\
\text { tillage }\end{array}$ \\
\hline \multirow{4}{*}{$1^{\mathrm{st}}$} & $11 / 7 / 2008$ & Spring & $0.083 \mathrm{Ab}$ & $0.081 \mathrm{Ab}$ & $0.085 \mathrm{Aa}$ & $0.090 \mathrm{Aa}$ & $0.097 \mathrm{Aa}$ & $0.094 \mathrm{Aa}$ \\
\hline & $11 / 14 / 2008$ & Spring & $0.049 \mathrm{Ab}$ & $0.055 \mathrm{Ab}$ & $0.056 \mathrm{Ab}$ & $0.070 \mathrm{Aa}$ & $0.075 \mathrm{Aa}$ & $0.073 \mathrm{Aa}$ \\
\hline & $11 / 21 / 2008$ & Spring & $0.033 \mathrm{Ab}$ & $0.033 \mathrm{Ab}$ & $0.032 \mathrm{Ab}$ & $0.051 \mathrm{Aa}$ & $0.054 \mathrm{Aa}$ & $0.053 \mathrm{Aa}$ \\
\hline & $11 / 27 / 2008$ & Spring & $0.039 \mathrm{Ab}$ & $0.037 \mathrm{Ab}$ & $0.036 \mathrm{Ab}$ & $0.049 \mathrm{Aa}$ & $0.046 \mathrm{Aa}$ & $0.048 \mathrm{Aa}$ \\
\hline \multirow{3}{*}{$2^{\text {nd }}$} & $3 / 10 / 2009$ & Summer & $0.058 \mathrm{Aa}$ & $0.060 \mathrm{Aa}$ & $0.058 \mathrm{Aa}$ & $0.054 \mathrm{Aa}$ & $0.055 \mathrm{Aa}$ & $0.053 \mathrm{Aa}$ \\
\hline & $3 / 17 / 2009$ & Summer & $0.042 \mathrm{Ab}$ & $0.040 \mathrm{Ab}$ & $0.038 \mathrm{Ab}$ & $0.052 \mathrm{Aa}$ & $0.052 \mathrm{Aa}$ & $0.050 \mathrm{Aa}$ \\
\hline & $3 / 24 / 2009$ & Autumn & $0.032 \mathrm{Ab}$ & $0.032 \mathrm{Ab}$ & $0.033 \mathrm{Ab}$ & $0.043 \mathrm{Aa}$ & $0.045 \mathrm{Aa}$ & $0.046 \mathrm{Aa}$ \\
\hline \multirow{2}{*}{$3^{\text {rd }}$} & $5 / 18 / 2009$ & Autumn & $0.060 \mathrm{Ab}$ & $0.063 \mathrm{Ab}$ & $0.058 \mathrm{Ab}$ & $0.068 \mathrm{Aa}$ & $0.072 \mathrm{Aa}$ & $0.065 \mathrm{Aa}$ \\
\hline & $5 / 25 / 2009$ & Autumn & $0.040 \mathrm{Ab}$ & $0.041 \mathrm{Ab}$ & $0.041 \mathrm{Ab}$ & $0.053 \mathrm{Aa}$ & $0.052 \mathrm{Aa}$ & $0.054 \mathrm{Aa}$ \\
\hline \multirow{3}{*}{$4^{\text {th }}$} & 7/3/2009 & Winter & $0.072 \mathrm{Aa}$ & $0.072 \mathrm{Aa}$ & $0.072 \mathrm{Aa}$ & $0.071 \mathrm{Aa}$ & $0.070 \mathrm{Aa}$ & $0.073 \mathrm{Aa}$ \\
\hline & $7 / 8 / 2009$ & Winter & $0.059 \mathrm{Ab}$ & $0.059 \mathrm{Ab}$ & $0.062 \mathrm{Ab}$ & $0.073 \mathrm{Aa}$ & $0.071 \mathrm{Aa}$ & $0.074 \mathrm{Aa}$ \\
\hline & $7 / 21 / 2009$ & Winter & $0.047 \mathrm{Ab}$ & $0.051 \mathrm{Ab}$ & $0.052 \mathrm{Ab}$ & $0.063 \mathrm{Aa}$ & $0.068 \mathrm{Aa}$ & $0.067 \mathrm{Aa}$ \\
\hline
\end{tabular}

(1) Means of soil tillage systems followed by the same capital letter for the same date and depth did not differ by the Tukey test $(p<0.05)$ and followed by the same lower-case letter on the same date did not differ by the $t$ test $(p<0.05)$.

Table 6. Soil water content in the 0-20 and 20-40 cm layer under two mulch management systems, in four drying periods and four seasons between 2008 and $2009^{(1)}$

\begin{tabular}{|c|c|c|c|c|c|c|}
\hline \multirow{2}{*}{$\begin{array}{l}\text { Drying } \\
\text { period }\end{array}$} & \multirow{2}{*}{ Date } & \multirow{2}{*}{ Season } & \multicolumn{2}{|c|}{$0-20 \mathrm{~cm}$} & \multicolumn{2}{|c|}{$20-40 \mathrm{~cm}$} \\
\hline & & & No Mulching & Mulching & No Mulching & Mulching \\
\hline \multirow{4}{*}{$1^{\mathrm{st}}$} & $11 / 7 / 2008$ & Spring & $0.085 \mathrm{Ab}$ & $0.081 \mathrm{Ab}$ & $0.094 \mathrm{Aa}$ & $0.093 \mathrm{Aa}$ \\
\hline & $11 / 14 / 2008$ & Spring & $0.049 \mathrm{Bb}$ & $0.057 \mathrm{Ab}$ & $0.072 \mathrm{Aa}$ & $0.074 \mathrm{Aa}$ \\
\hline & $11 / 21 / 2008$ & Spring & $0.031 \mathrm{Bb}$ & $0.035 \mathrm{Ab}$ & $0.048 \mathrm{Ba}$ & $0.057 \mathrm{Aa}$ \\
\hline & $11 / 27 / 2008$ & Spring & $0.035 \mathrm{Ab}$ & $0.039 \mathrm{Ab}$ & $0.045 \mathrm{Ba}$ & $0.051 \mathrm{Aa}$ \\
\hline \multirow{3}{*}{$2^{\text {nd }}$} & $3 / 10 / 2009$ & Summer & $0.058 \mathrm{Ab}$ & $0.059 \mathrm{Aa}$ & $0.051 \mathrm{Aa}$ & $0.057 \mathrm{Aa}$ \\
\hline & $3 / 17 / 2009$ & Summer & $0.040 \mathrm{Ab}$ & $0.040 \mathrm{Ab}$ & $0.050 \mathrm{Aa}$ & $0.053 \mathrm{Aa}$ \\
\hline & $3 / 24 / 2009$ & Autumn & $0.029 \mathrm{Bb}$ & $0.035 \mathrm{Ab}$ & $0.042 \mathrm{Aa}$ & $0.047 \mathrm{Aa}$ \\
\hline \multirow{2}{*}{$3^{\text {rd }}$} & $5 / 18 / 2009$ & Autumn & $0.062 \mathrm{Ab}$ & $0.059 \mathrm{Ab}$ & $0.070 \mathrm{Aa}$ & $0.067 \mathrm{Aa}$ \\
\hline & $5 / 25 / 2009$ & Autumn & $0.040 \mathrm{Ab}$ & $0.041 \mathrm{Ab}$ & $0.054 \mathrm{Aa}$ & $0.052 \mathrm{Aa}$ \\
\hline \multirow{3}{*}{$4^{\text {th }}$} & $7 / 3 / 2009$ & Winter & $0.072 \mathrm{Aa}$ & $0.072 \mathrm{Aa}$ & $0.073 \mathrm{Aa}$ & $0.070 \mathrm{Aa}$ \\
\hline & $7 / 8 / 2009$ & Winter & $0.058 \mathrm{Bb}$ & $0.062 \mathrm{Ab}$ & $0.072 \mathrm{Aa}$ & $0.073 \mathrm{Aa}$ \\
\hline & $7 / 21 / 2009$ & Winter & $0.047 \mathrm{Bb}$ & $0.053 \mathrm{Ab}$ & $0.065 \mathrm{Aa}$ & $0.067 \mathrm{Aa}$ \\
\hline
\end{tabular}

(1) Means of the mulch managements followed by the same capital letter for the same date and depth did not differ by the Tukey test $(\mathrm{p}<0.05)$ and followed by the same lower-case letter on the same date did not differ by the $t$ test $(p<0.05)$. 
trees grafted on "Cleopatra" mandarin rootstock (Cintra et al., 2000), corroborating the higher susceptibility to water stress of "Cleopatra" mandarin than of "Rangpur" lime (Pompeu Junior, 2005).

In the subsurface soil, a higher soil water content was measured at $20-40 \mathrm{~cm}$ depth (sandy clay loam texture) than in the $0-20 \mathrm{~cm}$ topsoil layer (sandy texture), regardless of soil tillage systems, mulching and rootstocks (Tables 5, 6 and 7), probably associated to the higher clay content (Fidalski et al., 2008, 2009, Machado et al., 2008) which reduce the drainage rate in this soil. In the spring, on November 21 and 27, 2008 , mulching had a positive influence on the soil
7) related to the higher transpiration rates of the orange trees grafted on this rootstock (Cintra et al., 2000).

The results of both evaluation series for soil water availability under orange tree rows showed that the residual tillage effect was temporary (observed only in 2007). On the other hand, effects of mulching and rootstocks were observed in the entire experimental period (2007, 2008 and 2009). These facts highlight the importance of mulching for soil water availability to orange trees regardless of the rootstocks specific to the soil and climatic conditions of northwest Parana, in Southern Brazil.

Table 7. Soil water content in the 0-20 and 20-40 cm layers, in four drying periods and four seasons between 2008 and 2009 , under two rootstocks of "Pêra" orange ${ }^{(1)}$

\begin{tabular}{|c|c|c|c|c|c|c|}
\hline \multirow[b]{2}{*}{$\begin{array}{l}\text { Drying } \\
\text { period }\end{array}$} & \multirow[b]{2}{*}{ Date } & \multirow[b]{2}{*}{ Season } & \multicolumn{2}{|c|}{$0-20 \mathrm{~cm}$} & \multicolumn{2}{|c|}{$20-40 \mathrm{~cm}$} \\
\hline & & & $\begin{array}{c}\text { "Rangpur" } \\
\text { lime }\end{array}$ & $\begin{array}{l}\text { "Cleopatra" } \\
\text { mandarin }\end{array}$ & $\begin{array}{c}\text { "Rangpur" } \\
\text { lime }\end{array}$ & $\begin{array}{l}\text { "Cleopatra" } \\
\text { mandarin }\end{array}$ \\
\hline \multirow{4}{*}{$1^{\mathrm{st}}$} & $11 / 7 / 2008$ & Spring & $0.083 \mathrm{Ab}$ & $0.083 \mathrm{Ab}$ & $0.094 \mathrm{Aa}$ & $0.093 \mathrm{Aa}$ \\
\hline & $11 / 14 / 2008$ & Spring & $0.055 \mathrm{Ab}$ & $0.052 \mathrm{Ab}$ & $0.074 \mathrm{Aa}$ & $0.071 \mathrm{Aa}$ \\
\hline & $11 / 21 / 2008$ & Spring & $0.033 \mathrm{Ab}$ & $0.033 \mathrm{Ab}$ & $0.055 \mathrm{Aa}$ & $0.051 \mathrm{Ba}$ \\
\hline & $11 / 27 / 2008$ & Spring & $0.037 \mathrm{Ab}$ & $0.037 \mathrm{Ab}$ & $0.047 \mathrm{Aa}$ & $0.048 \mathrm{Aa}$ \\
\hline \multirow{3}{*}{$2^{\text {nd }}$} & $3 / 10 / 2009$ & Summer & $0.057 \mathrm{Ab}$ & $0.060 \mathrm{Ab}$ & $0.053 \mathrm{Aa}$ & $0.055 \mathrm{Aa}$ \\
\hline & $3 / 17 / 2009$ & Summer & $0.042 \mathrm{Ab}$ & $0.038 \mathrm{Bb}$ & $0.052 \mathrm{Aa}$ & $0.051 \mathrm{Aa}$ \\
\hline & $3 / 24 / 2009$ & Autumn & $0.033 \mathrm{Ab}$ & $0.032 \mathrm{Ab}$ & $0.047 \mathrm{Aa}$ & $0.042 \mathrm{Ba}$ \\
\hline \multirow{2}{*}{$3^{\text {rd }}$} & $5 / 18 / 2009$ & Autumn & $0.061 \mathrm{Ab}$ & $0.060 \mathrm{Ab}$ & $0.069 \mathrm{Aa}$ & $0.067 \mathrm{Aa}$ \\
\hline & $5 / 25 / 2009$ & Autumn & $0.042 \mathrm{Ab}$ & $0.038 \mathrm{Bb}$ & $0.054 \mathrm{Aa}$ & $0.053 \mathrm{Aa}$ \\
\hline \multirow{3}{*}{$4^{\text {th }}$} & $7 / 3 / 2009$ & Winter & $0.071 \mathrm{Ab}$ & $0.072 \mathrm{Ab}$ & $0.073 \mathrm{Aa}$ & $0.070 \mathrm{Aa}$ \\
\hline & $7 / 8 / 2009$ & Winter & $0.059 \mathrm{Aa}$ & $0.061 \mathrm{Aa}$ & $0.073 \mathrm{Aa}$ & $0.073 \mathrm{Aa}$ \\
\hline & $7 / 21 / 2009$ & Winter & $0.051 \mathrm{Aa}$ & $0.049 \mathrm{Aa}$ & $0.066 \mathrm{Aa}$ & $0.066 \mathrm{Aa}$ \\
\hline
\end{tabular}

(1) Means of rootstocks followed by the same capital letter for the same date and depth did not differ by the Tukey test ( $p<0.05)$, and by the same lower-case letter on the same date did not differ by the t test $(\mathrm{p}<0.05)$.

water content in the layers 0-20/20-40cm (Table 6). These results confirm the importance of the Bw horizon under the A horizon as a water reservoir for orange trees, regardless of the rootstock.

In this experiment, the soil organic carbon contents in the plant rows did not differ statistically between the mulch management systems (Beraldo et al. 2007; Fidalski et al., 2009). The high sand content of this soil reinforces that the soil water content and availability at $0-20$ and $20-40 \mathrm{~cm}$ depth was influenced exclusively by mulching and by the different water consumption rates associated to rootstocks (Tables 6 and 7). The greater depletion of soil water in the soil under "Cleopatra" mandarin would indicate increased consumption (Tables 3, 4 and

\section{CONCLUSIONS}

1. The effect of soil tillage systems prior to orchard orange implantation on the soil water availability was less pronounced than of mulching and rootstocks.

2 . The soil water availability was lower under "Pêra" orange trees grafted on "Cleopatra" mandarin than on "Rangpur" lime rootstocks.

3. Mulching had a positive influence on the soil water availability in the sandy surface layer $(0-20 \mathrm{~cm})$ and sandy clay loam subsurface $(20-40 \mathrm{~cm})$ of the soil in the spring.

4. The production of $B$. brizantha between the rows and the residue disposal in the plant rows as mulch increased water availability to the "Pêra" orange trees. 


\section{ACKNOWLEDGEMENTS}

The authors wish to thank the Cocamar Cooperativa Agroindustrial for granting permission to use the experimental area. They would like to express their appreciation to the technicians Paulo Manoel de Lima and Wilson Schveiczrski, of IAPAR, for their assistance with soil sampling.

\section{LITERATURE CITED}

AULER, P.A.M.; FIORI-TUTIDA, A.C.G. \& TAZIMA, Z.H. Comportamento da laranjeira 'Valência' sobre seis portaenxertos no noroeste do Paraná. R. Bras. Frutic., 30:229. 234, 2008a.

AULER, P.A.M.; FIDALSKI, J.; PAVAN, M.A. \& NEVES, C.S.V.J. Produção de laranja 'Pêra' em sistemas de preparo do solo e manejo nas entrelinhas. R. Bras. Ci. Solo, 32:363-374, 2008b.

BANZATTO, D.A. \& KRONKA, S.N. Experimentação agrícola. 4.ed. Jaboticabal, Funep, 2006. 237p.

BERALDO, J.M.G.; AULER, A.P.M.; PAVAN, M.A. \& FIDALSKI, J. Reciclagem de nutrientes num pomar de laranjeira Pêra com diferentes sistemas de preparo de solo e cobertura vegetal. In: CONGRESSO BRASILEIRO DE CIÊNCIA DO SOLO, 31., Gramado, 2007. Anais. Viçosa, MG, Sociedade Brasileira de Ciência do Solo, 2007. CD-ROM.

BREMER NETO, H.; VICTORIA FILHO, R.; MOURÃO FILHO, F.A.A.; MENEZES, G.M. \& CANALI, É. Estado nutricional e produção de laranjeira 'Pêra' em função da vegetação intercalar e cobertura morta. Pesq. Agropec. Bras., 43:29$35,2008$.

CALHEIROS, R.O.; OLIVEIRA, D.; CARAMORI, P.H. \& GROSSI, M.E.D. Viabilidade técnica da irrigação em citros no norte e noroeste do Paraná. Pesq. Agropec. Bras., 27:963-973, 1992.

CINTRA, F.L.D.; LIBARDI, P.L. \& SAAD, A.M. Balanço hídrico no solo para porta-enxertos de citros em ecossistema de Tabuleiro Costeiro. R. Bras. Eng. Agríc. Amb., 4:23-28, 2000 .

CLAESSEN, M.E.E., org. Manual de métodos de análise de solo. 2.ed. Rio de Janeiro, Embrapa-CNPS, 1997. 212p. (Embrapa-CNPS. Documentos, 1)

FIDALSKI, J. \& TORMENA, C.A. Funções de pedotransferência para as curvas de retenção de água e de resistência do solo à penetração em sistemas de manejo com plantas de cobertura permanente em citros. Ci. Rural, 37:1316-1322, 2007.
FIDALSKI, J.; TORMENA, C.A. \& SILVA, A.P. Qualidade física do solo em pomar de laranjeira no noroeste do Paraná com manejo da cobertura permanente na entrelinha. R. Bras. Ci. Solo, 31:423-433, 2007.

FIDALSKI, J.; MARUR, C.J. \& TORMENA, C.A. Respostas fisiológicas da laranjeira 'Pêra' aos sistemas de manejo de cobertura permanente do solo nas entrelinhas. R. Bras. Ci. Solo, 32:1307-1317, 2008.

FIDALSKI, J.; BARBOSA, G.M.C.; AULER, P.A.M.; PAVAN, M.A. \& BERALDO, J.M.G. Qualidade física do solo sob sistemas de preparo e cobertura morta em pomar de laranja. Pesq. Agropec. Bras., 44:76-83, 2009.

HOGUE, E.J. \& NEILSEN, G.H. Orchard floor vegetation management. Hortic. Rev., 9:377-430, 1987.

INSTITUTO AGRONÔMICO DO PARANÁ - IAPAR. Cartas climáticas do Paraná: Edição ano 2000, versão 1.0. Londrina, 2000. CD-ROM.

MACHADO, J.L.; TORMENA, C.A.; FIDALSKI, J. \& SCAPIM, C.A. Inter-relações entre as propriedades físicas e os coeficientes da curva de retenção de água de um Latossolo sob diferentes sistemas de uso. R. Bras. Ci. Solo, 32:495$502,2008$.

POLITANO, W. \& PISSARRA, T.C.T. Avaliação por fotointerpretação das áreas de abrangência dos diferentes estados da erosão acelerada do solo em canaviais e pomares de citros. Eng. Agríc., 25:242-252, 2005.

POMPEU JUNIOR, J. Porta-enxertos. In: MATTOS JUNIOR, D.; DE NEGRI, J.D.; PIO, R.M. \& POMPEU JUNIOR, J., orgs. Citros. Campinas, Instituto Agronômico e Fundag: Fapesp, 2005. p.63-94

SANTOS, H.G.; JACOMINE, P.K.T.; ANJOS, L.H.C.; OLIVEIRA, V.A.; OLIVEIRA, J.B.; COELHO, M.R.; LUMBRERAS, J.F. \& CUNHA, T.J.F., eds. Sistema brasileiro de classificação de solos. 2.ed. Rio de Janeiro, Embrapa Solos, 2006. 306p.

STENZEL, N.M.C.; NEVES, C.S.V.J. \& SCHOLZ, M.B.S. Comportamento da laranjeira 'Folha Murcha' em sete porta-enxertos no noroeste do Paraná. R. Bras. Frutic., 27:408-411, 2005a.

STENZEL, N.M.C.; NEVES, C.S.V.J.; MARUR, C.J. \& GOMES, J.C. Crescimento vegetativo de plantas cítricas no norte e noroeste do Paraná. R. Bras. Frutic., 27:412-417, 2005b.

TOPP, G.C.; DAVIS, J.L. \& ANNAN, A.P. Electromagnetic determination of soil water content: Measurements in coaxial transmission lines. Water Res. Res., 16:574-582, 1980. 